\title{
TOWARDS A MODEL OF THE PLACE BRAND WEB
}

\begin{abstract}
Conceptual and empirical study of place brand architecture is limited. In order to address this gap, this article uses a two-stage mixed method study involving interviews with place brand practitioners and web content analysis. The article, first reports on the challenges associated with managing place brand relationships and, then, discusses various aspects of the brand webs associated with places. On this basis, the article proposes, exemplifies and discusses the Place Brand Web Model. This model, which responds to the complex nature of the relationships between the brands associated with a place, is presented in two instantiations, the DMO perspective, and the more generalised perspective that views brands with associations with a place as contributing to the co-creation of the perceptual entity, THE Place Brand. The model is exemplified and discussed and with reference to a major UK city.
\end{abstract}

Keywords Place branding; brand architecture; brand leadership; stakeholders; place brand web.

\section{Introduction}


It is widely recognised that, like a corporate brand, a place brand can act as an umbrella brand to support the promotion and branding of various products, services and places associated with a given place (Anholt, 2004; Iversen \& Hem, 2008). Leadership in place branding has, typically been viewed as resting with Destination Marketing Organisations (DMO's). In this study, in order to accommodate the dynamic nature of place branding, we adopt a generic notion of a DMO as the organisation that is perceived as leading the place branding initiatives associated with a given place. The term DMO is applied to those organisations that take a generic role in place branding, with a view to engaging and attracting tourists, businesses, cultural and sporting events and locales, and public and private sector investment. This is consistent with the adoption of an integrated theoretical approach to place branding (Gnoth, 2002; McCarthy, 2007; Peel \& Lloyd, 2008), and is supported by the widespread acknowledgment of the importance of buy-in from other organisations with important brands associated with the place (Briggs, 2009; Iversen \& Hem, 2008).

Understanding and being able to identify the brand architecture associated with a place is a pivotal aspect of articulating the tourism offering and managing the tourism experience associated with place. However, limited attention has been directed towards place brand architecture or the wider management of the web of brands associated with a place. Important exceptions are the contributions from Anholt (2004), Braun and Zenker (2010), Inversen and Hem (2008) on brand architecture in place branding, in general, and Datzira-Masip and Poluzzi (2014), Dooley and Bowie (2005) and Hankinson (2005, 2009) on destination brand architecture. Both Anholt (2004) and Hankinson (2005) argue that places should have an identified brand architecture that embraces a portfolio of brands, and Mihailovich (2006) asserts that a coherent place brand architecture is fundamental as a structure for forging alliances. In addition, in the context of destination brand architecture, Datzira-Masip and Poluzzi (2014, p. 48) emphasise that since the sector is 'composed of a multitude of private and public players, each of them promoting their own product brand' there is a significant lack of attention being paid to brand architecture. In addition, the overlap and interrelationships between place brands at the local, regional and national level serve to further strengthen the case for further work in this area.

This research then, seeks to contribute to the development of the notion of place brand architecture, and advance understanding of the web-of-brands associated with a place or destination, through a two-stage study that gathers empirical data on place brand 
relationships, with the overall aim of proposing, exemplifying and discussing an allembracing model of the place brand web. Further, whilst acknowledging the importance of the relationships between the stakeholders associated with a place in facilitating meaningful place brand architecture, this article does not elaborate on these relationships or their associated processes, but rather centres its considerations on the relationships between the brands associated with a place. As such, this research should be of interest to all stakeholders, individual and organisational, who have a role in promoting and contributing to a coherent place identity; this includes traditional DMOs, regeneration agencies, local authorities, community groups and commercial and voluntary sector organisations.

Stage 1 of this study adopts the conventional notion of place brand architecture, and is based on interviews with place brand practitioners in DMO's in various locations, exploring their perceptions of the challenges associated with managing place brand architecture. At this stage, the focus is on 'brand architecture', the process of designing and managing a portfolio(s) of the places' sub-brands owned by the communities associated with the place (Hanna \& Rowley, 2011). The aim of this stage is to:

1. Offer insights into the approaches to and the challenges associated with managing relationships between the brands associated with a place, with a specific focus on the role of leadership, stakeholder engagement, place infrastructures (physical and experiential), and the adoption of visual identities.

Stage 2 of this study is based on an exploratory two-stage web-page content analysis that investigates the nature of the web of place brands associated with a place, not all of which lie within the remit of the DMO. The aims of this stage are to:

2. Explore the web of brands associated with a place, and

3. Propose, exemplify and discuss the Place Brand Web.

At this stage, the focus of the study is on the wider place brand web, which defines the brand space within which any DMO or other branding organisations associated with a place are to operate. The notion of the place brand web is based on parallel concepts in the corporate branding literature, the brand-web, proposed by Leitch and Richardson (2003) and developed by Uggla (2006) in the 'corporate brand association base' model. These models centre on the concept of co-branding, which involves the public linkage of partner brands in order to enhance the value of both brands (Motion, Leitch \& Brodie, 2003).

Stage 1 of the study acts as platform for Stage 2. Stage 1 investigates the current situation and challenges to managing the web of brands associated with a place, and generally 
establishes the need for further research in this area. Stage 2 responds to this need, by further elaborating on the types of brand relationships associated with place brands, as a precursor to the proposal of a theoretical model as the basis for analysis and dialogue.

\section{Literature Review}

\subsection{Approaches to Brand Architecture}

Brand architecture, a theory belonging to conventional branding, is described as the organising structure of the brand portfolio that specifies brand roles and the nature of the relationships between brands (Sanchez, 2004). Brand architectures are often seen as hierarchical with some brands being viewed as subordinate to, or sub-brands of, other brands. The conventional strategies of brand architecture include house-of-brands and branded-house. House-of-brands is where an organisation has a number of independent brands each with their own values and characteristics; this accommodates differentiated positioning and limits negative brand reputation transfer. Datzira-Masip and Poluzzi (2014) suggest that the Balearic Islands use the house-of-brands model since the individual islands such as Majorca are more visible than the brand of the Archipelago. Alternatively, a branded-house strategy seeks to transfer organisational values to all of its brands. The Maldives use the brandedhouse approach since the names and characteristics of the single islands are unrecognised but the generic characteristics of the Maldives are well known (Datzira-Masip and Poluzzi, 2014). Between house-of-brands and branded-house, there are various hybrid options including the sub-brand and endorsed brand strategies (Aaker \& Joachimsthaler, 2000). The difference between sub-brand and endorsed brand strategies is subtle. In sub-brand strategies, there is greater affiliation between the sub-brands and their master brand. For example, the sub-brands of Perth and Gascoyne use, with some visual adaptation allowing for some individuality, the template of their master brand, Western Australia. Conversely, in an endorsed strategy the master brand plays a far less prominent role, with the link between the sub-brands and the master brand being perceptual. For example, in promoting the skiing destinations, Iceland, Denmark, Sweden, Norway and Finland are presented a single entity, under the banner of 'Scandinavia' (Dooley and Bowie, 2005).

As a point of departure for conceptualising place brand architectures, prior studies have taken brand architectures in corporate branding and compared corporate branding and city brands (Kavaratzis, 2004; Olins, 2003; Trueman, Klemm \& Giroud, 2004) and examined similarities to corporate umbrella branding (Gnoth, 2002; Iversen \& Hem, 2008; 
Papadopoulos \& Heslop, 2007; Therkelsen \& Halkier, 2008). However, scholars have begun to identify specific challenges associated with the development of such a strategic approach. An important consideration is the link between the brand architecture and the 'organisation's' intended strategy (Aaker \& Joachimsthaler, 2000). Achieving this link presents a particular challenge since place brand architecture is an interactive and evolutionary process affected not only by intended strategy but also by past and present place factors (Douglas \& Craig, 2002; Hanna \& Rowley, 2011).

Places evolve according to stakeholder needs and changing desires, traditions, technologies and economies (Van Assche \& Lo, 2011). In addition, the evolution of place strategy is a political process having associations with governance (Eshuis, Braun \& Klijn, 2013), and involves engaging with the interests and aspirations of multiple stakeholders (Therkelsen \& Halkier, 2008), such that "branding is seldom under the control of a central authority” (Iversen \& Hem, 2008, p.604). A further challenge arises from the geographic context associated with a place brand. Whilst, corporate brands are applied to products and services within a corporate organisational framework, place brands are applied to products and services within a political and geographic framework (Allen, 2007; Hankinson, 2009). The geographical context of place brands presents the issue of boundaries and their impact on the notion of place brand architecture. For instance, research conducted by Hankinson (2009) found that in regional branding (UK) conflicts could emerge between the region, its cities and towns, each protecting its interests in having its own brand. Similarly, Warnaby (2009) asserts that an area's boundaries are often unclear or overlapping, causing 'place fuzziness' where the territory marketed is not always the same as the territory consumed. Both authors argue that brand architecture is a political issue affecting cooperative structures and outcomes. In acknowledging such conflicts and striving for a solution, Hankinson (2009) advocates the adoption of a branded-house strategy.

Overall, from a practical perspective the fundamental challenge for place brand practitioners is the lack of direct control over the place brand. Hence, whilst concepts such as brand architecture might usefully be borrowed from mainstream branding theory, both the concepts and their implementation may require adaption in the context of place branding.

Given the unique characteristics of place branding, the more fluid models of brand relationships that have been developed to aid understanding of corporate co-branding and its relationships may be more applicable than traditional models of brand architecture. For instance, the 'corporate brand association base' (Uggla, 2006) links the corporate brand with 
its surrounding environment through partner associations. For place brands, such partner associations may include other place or service bands, persons with strong associations with a place and institutional cultural associations.

\subsection{Aspects of place brand management impacting place brand architecture}

\subsubsection{Brand Leadership}

The responsibility for developing place brands largely rests with DMO's, mainly located in the public sector, such as tourism boards, regional development agencies and local government departments. Overall, the significance of leaders in providing focus and delivering on brand strategy is widely recognised (Aaker \& Joachimsthaler, 2000; Hankinson, 2007, 2009; Rubenstein, 1996; Simoes \& Dibb, 2001).

Aaker and Joachimsthaler (2000) depict the brand manager as a strategist, a communications team leader and a creator of vision. Further, they recognise the importance of building brand equity and the complex structures of branding and argue that one of the challenges for aspiring leaders is brand architecture, which enables them to identify brands, sub-brands, and their relationships and roles. More specifically in the context of place branding, Ooi (2004) emphasizes the lack of authority among national actors to implement a national branding strategy and the need for persuasive and consensus-based efforts to attain collaboration. Hankinson (2007) suggests that vision and core-values are the precursor to the wider brand strategy debate held with potential partners who will eventually execute the strategy. The challenge for leadership is to define some unifying values which capture the complexity of the place's portfolio of offers and that can also be potentially extended across diverse stakeholder groups. This is a particularly cumbersome task due to the places' multifaceted offers and cross-sector collaborations.

Anholt (2004 in: Morgan, Pritchard \& Hide, 2004) and Hankinson (2005) assert that an analysis of the prioritisation, viability and compatibility of each market should contribute to the structure of the brand architecture, suggesting that managed branding processes should commence with an audit to assess the current situation. In particular, in an early work, Douglas and Craid (2002) make a range of propositions regarding the audit of brand architectures, and discuss the assessment of stakeholder functions as part of the overall place brand architecture. They suggest that an evaluation of the overall brand architecture should be conducted to determine the fit with established guidelines across multiple sectors, and to monitor changes in the underlying drivers of brand architecture, and in the place. 


\subsubsection{Stakeholder Engagement}

Stakeholders can include any group or individual ${ }^{1}$ that can be affected by the achievements of the objectives of the organisation (Sautter \& Leisen, 1999). It is further argued that each stakeholder has the right to be treated as an end in themselves and not as a means to an end (Donaldson \& Preston, 1995; Jones, 1995), therefore stakeholders can and should have a direct influence on managerial decision making. Stakeholder theory argues that it is the responsibility of leadership to select activities that obtain optimal benefits for all identified stakeholders, regardless of their relative power or interests (Clarkson, 1995; Donaldson \& Preston, 1995; Jones, 1995). Yet, in this task and in the context of place branding, leadership is hugely hampered by a variety of political pressures, including the reconciliation of local and regional interests and the promotion of an identity that is acceptable to a range of public and private sector organisations.

DMOs recognise the need to manage a series of separate relationship networks comprising public and private sector organisations (Hankinson, 2007). These organisations are involved in various industries, each of which has a myriad of players who often act independently of each other and over whom the DMO has little or no control, yet this diverse range of agencies and organisations are all stakeholders in the place brand. In addition, where the industry mostly exists of SME's, these stakeholders will only have limited resources (time, money, manpower) available to collaborate (Riege, Perry \& Go, 2001). This lack of congruence (Sautter \& Leisen, 1999) and limited resources impede coordination between the various stakeholders. Conversely, the success of a place brand depends on the effectiveness of leadership in generating brand commitment (Burmann \& Zeplin, 2005). Typically, leadership seeks to cultivate this commitment through stakeholder discussions that aim to identify brand values that would benefit the place brands' multiple stakeholders (Moilanen \& Rainisto, 2009). Iversen and Hem (2008) argue for vertical and horizontal coordination where the former identifies a vision that benefits stakeholders within one industry sector, while the latter does so across various sectors. The ideal is that different stakeholders associated with the brand are able to act autonomously whilst also committing to the place brand. Accordingly, a participatory approach with collaboration between industry representatives through steering and advisory groups is proposed (Briggs, 2009).

\footnotetext{
${ }^{1}$ Stakeholders include: residents; activist groups; competitors; local businesses; employees; national, regional and local government; national business chains; and tourists.
} 


\subsubsection{Place Infrastructure: physical and experiential}

One of the unique facets of place branding is the dynamic between the brand and the place infrastructure. Owing to the physical reality of a place, the experience is the actual product and has many and differing instantiations (Gnoth, 2004).

Place infrastructure constitutes the brands' existent, accessible and sufficient functional (tangible) and experiential (intangible) attributes (Baker, 2007; Cai, 2002; Hankinson, 2004; Kavaratzis, 2004; Moilanen \& Rainisto, 2009). Functional attributes are realised through the place's infrastructure and its landscapes, which embrace the built environment and public spaces, including their urban design and architecture. Experiential attributes arise from a combination of symbolic traits and functional attributes. Symbolic traits include the provision of cultural entertainment and services. Here, the elements of significance are the types of services provided, the effectiveness of their provision and the number and types of provisions (Kavaratzis, 2004). Moilanen and Rainisto (2009, pp. 185-187) argue that services may be the basis of the most substantial differential advantage when considering consumer brand experiences. On the other hand, the literature is relatively silent on the link between place infrastructure and place brand architecture. One useful contribution that obliquely addresses this link is provided by Gold (2006) in their discussion of Intellectual Brand Architecture. They suggest that the ability to stimulate cultural, social and technological creation makes a place's intellectual architecture critical to its brand; it is what makes claims made by a marketing campaign true.

Equally, from a consumption perspective, DMO's cannot control consumer experiences. Consumers decide for themselves which aspect of the place to consume. Places have at least three types of consumers: (1) inhabitants searching for a place to work live and relax; (2) firms looking for a place to do business, locate and look for employees; and (3) visitors seeking leisure and tourists opportunities (Van Assche \& Lo, 2011). In addition, there are large differences within each of these three stakeholder groups arising from differences in age, lifestyle, income and knowledge of the place. Overall, the brand architecture derives from and should be substantiated in terms of what the place can offer, with any representation embracing the need to communicate to various audiences.

\subsubsection{Visual Identity}


Leadership must establish structures that convey coherent and consistent brand messages through the place brand's visual identity (Vallaster \& DeChernatony, 2006). Place branding, in contrast to corporate branding, is a collective phenomenon, involving a number of stakeholders; DMO's must consider how the multidimensionality of a place can be captured, through collaboration. Collaboration however, is not without risks. Overstretching the master brand's visual identity in an attempt to achieve commonality can dilute the effect of each sub-brand and vice-versa (Chen \& Chen, 2000; Dooley \& Bowie, 2005; Kotler \& Gertner, 2002; Martinez \& Pina, 2003; Hankinson, 2009). In this context, Therkelsen and Halkier (2008) discuss the importance of inter-organisational relations between promotional bodies arguing that in order to be efficient, a cross-sectional communication platform has to take into account the functional contexts in which recipients will be interpreting the brand.

Braun and Zenker (2010) discuss brand architecture more specifically with reference to the need for a portfolio of place brand visual identities. They propose a conceptual model, 'the place brand centre', which presents the DMO with a management structure that targets group-specific sub-brands. They use Berlin as an example. The city's branding campaign "be Berlin", was aimed at strengthening the identity of Berlin residents, but this message was not suitable for tourists and investors. Accordingly, they developed distinct sub-brands for tourists (visit Berlin) and for investors (invest in Berlin), to enable targeted group-specific communication and the creation of strong sub-brand perceptions within the target groups.

\section{Methodology}

\subsection{Approach}

This study adopts a two-stage approach, incorporating both interviews and web-site content analysis to explore different aspects of the study phenomenon, place brand architecture. This study, guided by a pragmatist philosophy, adopts an approach in which both methods are essentially applied from a qualitative stance, such that surfacing and constructing meaning pervades both stages. Given the limited prior research on place brand architectures, the study adopts an inductive stance, and combines the two methods to study different aspects of the phenomenon (Bryman \& Bell, 2011).

\subsection{Stage 1: Approaches to managing place brand architectures.}


This stage of the research was part of a wider study on the process of strategic place brand management (SPBM) and its components (Hanna \& Rowley, 2011, 2013). One of these components was brand architecture.

Findings are based on interviews with fifteen participants with a range of backgrounds including a chief executive, marketing and communications directors and managers as well as regeneration managers and executives, marketing officers and funding managers. Each participant worked for a DMO associated with a different place, and had direct responsibility for place brand management. In keeping with the participants' wishes for anonymity, place names are substituted for P1, P2, P3...etc. Participants were recruited from DMO's associated with towns, cities, and regions (see Table 1). Convenience sampling was adopted, and was guided by the following criteria: the balance of town, cities and regions, distance of travel, and willingness to participate. Participants were initially contacted by telephone, and then by e-mail to arrange a face-to-face interview at the interviewee's place of work. Questions in the interviews focussed on the following themes:

- The brand relationships within the place,

- What they perceived their role to be in relation to facilitating those relationships,

- How they sought to achieve stakeholder engagement and commitment towards mutually beneficial place brand architecture,

- Their understanding of the impact of place infrastructure on brand architecture,

- The way in which they attempted to manage the brand visuals so that they reflected the brand architecture. 


\begin{tabular}{|c|c|c|c|}
\hline \multicolumn{2}{|r|}{15 Interviewees } & \multirow{2}{*}{$\frac{\text { Symbol }}{\mathrm{P} 1}$} & \multirow{2}{*}{$\begin{array}{l}\text { Type of DMO } \\
\text { Tourism agency }\end{array}$} \\
\hline$\stackrel{+}{\ddot{E}}$ & $\begin{array}{l}\text { Head of services/marketing } \\
\text { communications }\end{array}$ & & \\
\hline & Urban regeneration manager & $\mathrm{P} 2$ & $\begin{array}{l}\text { Economic development } \\
\text { company }\end{array}$ \\
\hline & $\begin{array}{l}\text { External funding manager/economic } \\
\text { strategist }\end{array}$ & P3 & $\begin{array}{l}\text { Economic development } \\
\text { company }\end{array}$ \\
\hline & $\begin{array}{l}\text { Tourism and marketing development } \\
\text { manager }\end{array}$ & $\mathrm{P} 4$ & Urban regeneration company \\
\hline \multirow{6}{*}{$\stackrel{\circ}{\ddot{\circlearrowright}}$} & Marketing director & P5 & Local government authority \\
\hline & Head of marketing & P6 & $\begin{array}{l}\text { Independent public/private } \\
\text { organisation }\end{array}$ \\
\hline & Regeneration executive & $\mathrm{P} 7$ & Local government authority \\
\hline & Marketing manager & P8 & Local government authority \\
\hline & Culture park manager & P9 & Local government authority \\
\hline & Chief executive & $\mathrm{P} 10$ & Local government authority \\
\hline \multirow{5}{*}{ 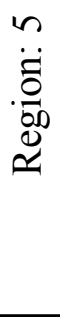 } & Marketing director & $\mathrm{P} 11$ & Regional development agency \\
\hline & Marketing officer & $\mathrm{P} 12$ & Local government authority \\
\hline & Communications director & $\mathrm{P} 13$ & National park authority \\
\hline & Marketing director & P14 & Tourism board \\
\hline & Marketing officer & $\mathrm{P} 15$ & Regeneration partnership \\
\hline
\end{tabular}

Table 1: Details of DMO's Interviewed

In judging the optimum number of interviews, the researchers were guided by Polkinghorne (1989), Creswell (1998, 2007) and Kvale and Brinkmann (2009) who recommend that researchers interview between five and twenty five individuals who have all experienced the phenomenon, provided that they are long interviews. Moreover, Kvale and Brinkmann (2009) and Knox and Burkard (2009) suggest interviewing as many individuals as necessary to reach saturation, while Guest, Bunce and Johnson (2006) found that saturation occurs within the first twelve interviews, with basic elements for common themes being present as early as after six interviews. Such assertions are supported by various publications that have gathered and analysed place branding interview data from five to eighteen participants (Bennett \& Savani, 2003; Hankinson, 2001, 2005, 2009; Park \& Petrick, 2006; Stubbs, Warnaby \& Medway, 2002). 
Responses to the questions were recorded, transcribed, and subsequently analysed using thematic analysis (Creswell, 1998). The analysis involved the extraction of significant statements, sentences and quotes designed to generate an understanding of participants' views on the meaning of place brand architecture and its management. Moustakas (1994, p. 97) calls this step horizonalization.

Meanings were then formulated from the significant statements and were clustered into themes allowing for the emergence of common themes according to the participants' transcripts. To deduce the meanings in their original context the significant statements were read, re-read and reflected upon in the transcripts. The themes were then referred back to the transcripts in order to validate them. In support of Moustakas (1994), Creswell (1998) states that confirmation is achieved by repeated looking, viewing and checking for themes against transcripts to see if they are expressed explicitly or if they are compatible.

\subsection{Stage 2: Exploring the web of brands associated with a place}

The methodology adopted for this stage is a selective content analysis of the web presence of place brands, on key websites associated with the selected place. This approach has been adopted as the Internet:

- Is an important medium though which people encounter place marketing and branding,

- Offers easy identification of the various instantiations of place brands and representations associated with any specific place entity,

- Facilitates comparisons between a larger number of places.

Moreover, there is increasing interest in developing approaches to mining the contents of websites to support increased understanding of place marketing and branding (Hashim \& Murphy, 2007; Munar, 2011; Trueman, Cornelius \& Wallace, 2012).

In Phase 1, websites associated with cities in the UK were identified, in order to explore the websites associated with each city, the organisations responsible, brand colour palettes, and any links between the different web sites associated with the place. The approach adopted is similar to that adopted by Dooley and Bowie (2005) and Dattzira-Masip and Poluzzi (2014), who examined common elements in logos, such as colour and design as a representation of relationships between brands.

In Phase 2, the case of one major UK city, Liverpool was explored further, with a view to developing an exemplar of the complex web of brands associated with major cities. Case research was chosen for this part of the study because it supports a more in-depth analysis of 
a situation and allows for the choice of interesting cases (Yin, 2009). Further, there is a strong tradition of case study research in place branding (Olins, 2003; Trueman, Klemm \& Giroud,. 2004). Liverpool was chosen as the case study for this part of the research due to its ongoing place branding efforts, the recent initiatives of Marketing Liverpool, and the rich range of other organisations and brands associated with the city. In this phase, the methodology involved the identification of organisational website(s) that in some way promoted the place, Liverpool. Such sites were identified through several cycles of Google searches, based around the search term 'Liverpool'. The intention was not to collect an exhaustive list of such organisations, but rather to identify organisations with an easily accessible webpresence, and to develop an understanding of the different types of organisations that could be perceived as supporting the brand 'Liverpool', either implicitly or explicitly, and which could therefore be viewed in one sense or another as part of Liverpool's Place Brand Web. Further information on potentially relevant organisations was gleaned from the website of Marketing Liverpool, Liverpool Vision's destination marketing initiative. Once appropriate organisational websites had been identified they were visited in order to explore the sense in which they might be viewed as promoting Liverpool, and specifically whether they used either the Marketing Liverpool brand logo, or the name of the city on their web page.

\section{Findings and discussion}

4.1 Stage 1: Approaches to and challenges associated with managing place brand architectures (objective 1)

\subsubsection{Approaches to brand architecture}

The study found that brand architecture in place branding is applied within a political and geographical framework (Allen, 2007; Hankinson, 2009; Warnaby, 2009). Whether the place brand becomes a branded-house or a house-of-brands, it is influenced by political and geographical boundaries. Participants were concerned to offer a holistic brand, and to avoid segmentation on the basis of different customer segments, arguing that to do so would have weakened if not diminished the brand's value (Chen \& Chen, 2000; Dooley \& Bowie, 2005; Kotler \& Gertner, 2002; Martinez \& Pina, 2003); as one participant stated: “Our brand is for the... whole district...the rural areas look to town for their services...the town looks to the rural areas for quality of life...the town... by itself cannot deliver our values" (P1).

Consumers' perceptions of the brand and its relationships to other place brands was a central consideration in deciding whether to introduce sub-brands (P12); as one participant 
stated: "Manchester...obvious everything fits around Manchester, in Cumbria their attack brand is the Lakes, Cumbria is the overarching brand" (P15).

Further, where the brand is attempting to establish a recognisable identity it was advisable to integrate communications under a branded-house strategy to denote gravitas (P12). Conversely, where the place has a long history and an associated brand or place name that has become the context through which its community has expanded and evolved, in line with Warnaby (2009), awareness of the strength of the brand by neighbouring constituencies was inevitable; as one participant stated: "If you're outside the legal boundary of the park...that doesn't mean things don't permeate across boundaries...we may work outside it, I haven't come across anyone who doesn't want to be part of the brand" (P13).

Further analysis of the type of brand architectures adopted by the place brands revealed that for most brands it was not possible to identify a clear brand architecture on the basis of the categories in Aaker and Joachimsthaler (2000)'s typology. No towns had an identified brand architecture, and the two cities (P5, P10) with an identified brand architecture both used a branded house approach. The greatest diversity of brand architectures was in evidence in the region category. In this group, two of the regions (P13, P14) were using a mix of brand architectures, rather than adopting just one specific strategy, demonstrating a more fluid approach to the management of the place brand relationships (Leitch \& Richardson, 2000; Uggla, 2006). It would appear that brand managers are to some extent blocked in their aspirations to treat brand architecture strategically by lack of an adequate level of stakeholder commitment; as one participant stated: "Our stakeholders have their own identities... targeting different groups they are welcome to adopt the brand but it is an area of conflict" (P6).

Moreover, participants often viewed their success in this area in terms of the extent of adoption of the place brand logo in the visual identity by other place stakeholders; as one participant stated: "Our goal is to increase usage...by organisations... where we work jointly on things we always have the place logo on ...but stakeholders working on their own material will not necessarily use the logo" (P11).

\subsubsection{Brand leadership}

Participants viewed themselves as having responsibility for place brand leadership, and for the development of the place brand architecture. Overall, effective communication and 
stakeholder collaboration, within a highly complex, diverse, and politicised stakeholder environment was central to leadership's role in developing brand architecture.

There was a general consensus that leadership cannot develop a place brand independently and recognition of the need for input from stakeholders in brand development. In keeping with Sautter and Leisen (1999), participants recognised that as congruence across stakeholder groups increases so does the likelihood of collaboration and compromise. They also felt that achieving a co-ordinated brand architecture depended on the DMO's objectives and on the resilience and expertise of leadership in articulating their proposition; as one participant stated: "Buy-in from...communities...depends on...the extent you want to engage with them...to which extent you want to influence" (P9).

Participants also commented on the need for open stakeholder communications (Aaker \& Joachimsthaler, 2000) to highlight any conflicts of interest, and the use of informal communications procedures and forums to resolve such conflicts (P12, P7, P6, P11). It was also noted that brand architecture was dependent on evolving market demographics and economic stability (Douglas \& Craig, 2002; Hanna \& Rowley, 2011; Van Assche \& Lo, 2011) and essential for brand longevity (P10, P8, P6). For instance, the foot and mouth epidemic was a factor in changing strategy and brand perspectives to exploit positive associations (P14). Others recognised that "the world does not stand still [you]...are trying to work with change" (P11).

\subsubsection{Stakeholder Engagement}

There is a consensus that aligned brand architecture is heavily dependent on stakeholder engagement, as one participant stated: "It is politically important for us to listen to trade and try and integrate their ideas" (P12).

However, there is also a degree of complacency and the inclination to make progress regardless (P4, P6), as a result of difficulties arising from managing the ambiguities and inefficiencies associated with trying to accommodate various stakeholders. Hankinson (2007, 2009) asserts that in order to engage stakeholders, place brand managers need to provide focus and strategy, whilst Burmann and Zeplin (2005) suggest that successful leaders act as interrogators. As such, one participant stated: "If we...had opposition...to an idea that aligned with our economic strategy the reply is it is not about whether you like it or not, it is part of our identity and our brand and you cannot argue with that, so then you have streams falling into line if it was a strategic move” (P15). 
For engagement to function efficiently, stakeholders must identify with the brand corevalues so that they do not feel imposed upon (P1, P7). However, place brand managers, whilst engaging with and responding to multiple stakeholders, must ensure that the brand core-values are not diluted. One solution was to adopt sub-brand strategies (Dooley \& Bowie, 2005; Martinez \& Pina, 2003; Uggla, 2006) whilst still maintaining a common denominator (P10).

The participants contended that place brand architecture it is about building relationships that recognise the importance of serving individual objectives while also considering the purpose of those sub-brands in the wider context (Miller, 2002), as one participant stated: "The community...thought everything that happened here was for the benefit of the visitor...actually it is your town and we want to know what you think...want of it...that would be of benefit to the visitor as well" (P2).

Ultimately, successful engagement for the adoption of the place brand is dependent on stakeholder satisfaction with the proposed benefits (Molianen \& Rainisto, 2009), as one participant stated: "Some public and private organisations dispensed...with their identity...became fully fledged sub-brands...but there is still a great number of organisations not using the brand" (P10).

\subsubsection{Place Infrastructure: physical and experiential}

Participants recognised that the place product is two dimensional, encompassing functional and experiential attributes where the latter is dependent on the former while the execution of both should aim to deliver consumer satisfaction (Baker, 2007; Cai, 2002; Hankinson, 2004; Moilanen \& Rainisto, 2009).

Although the literature only makes passing comment on the link between the place infrastructure and its brand architecture (e.g. Gold, 2006), participants agreed that the brand architecture should be substantiated in terms of what the place can actually offer. Overall, recognition of the place's level of competitiveness is dependent on the quality and nature of the infrastructure; you cannot have an element of a brand identity without the infrastructure to support it (P12, P5), as one participant stated: "If you're saying that you're a modern city that embraces international markets... [you] have to have the product to offer that" (P5).

Thus, the need to account for local context was acknowledged with participants stating that where the place has evolved from favourable historical roots brand management should support infrastructure initiatives reminiscent of a historical era to foster commitment and 
evoke pride of place. In other words, place infrastructure has to be visionary and ambitious but rooted within the reality (P7) (Miller, 2002).

Given the centrality of place infrastructure to both the brand identity and experience, place infrastructure development is central to place brand development, including the development of the place brand architecture. However, influencing infrastructure development through engagement with stakeholders is great in theory but difficult in reality (P8). Negotiations must be resilient, but also avoid alienating stakeholders, such as residents, investors and visitors, whilst aligning with market requirements. As one participant stated: "We asked the surrounding services what they want... you have to strike a balance between what the council thinks its priorities are and ...negotiation with the developer" (P1).

In addition, the authority to influence or direct expenditure with regard to brand infrastructure is based on the source of the funding and the legislative basis of the lead organisation. For instance, resources for larger projects, such as roads, come from central government; brand leadership cannot influence these decisions nor can it influence their priority listing by central government (P1). Similarly a tourism board has no influence over regeneration initiatives that are publically funded (P14). Organisations that are funded by central government but are independent due to their legislative basis are autonomous (P13). Similarly, where the organisation is publically funded through partnership the brand would be allocated a budget from a mix of partnership agencies (P6). In general, then the range of agencies and partnerships associated with infrastructure development can pose difficulties in developing an aligned place brand architecture, and, at best may introduce greater complexities into the brand architecture associated with a place.

Consequently, in the realm of place brand infrastructure, majority funders control expenditure, thereby limiting the influence of place brand leaders or the DMO. Here the implementation of brand architecture strategies is affected by the collective orientation of internal/external stakeholders associated with the place. In this sense, traditional brand architecture does not accommodate the interactive nature of place branding, which is not only affected by the intended and negotiated strategy of the DMO, but also by stakeholders' authorities (Douglas \& Craig, 2002; Allen, 2007).

\subsubsection{Visual Identity}

While brand architecture was viewed as an important component of the place branding process, it became apparent that of the fifteen DMO's interviewed only a limited number (P5, 
P11, P15) have a sense of a formal and specific brand architecture, which they carry through to their visual identity.

Overall, it was agreed that brand architecture should be grounded in presenting the consumer with an identifiable and accurate image (P6). This image can be guided by the past, and the future (P5, P7, P13). It must be relevant and not detached from the reality, as one participant stated: "We looked for visualisation that would have...the feel of a back stamp...resulted after speaking to hundreds of people so our colours and feel...[are] about [our] industrial past and heritage...used terracotta's and greys...colours that mean something” (P15).

Additionally, the independence of stakeholder brands must be respected (P3, P15) when requesting endorsement (Hankinson, 2009). Endorsement of the place brand by stakeholders is subject to visual representations of the brand in marketing material being restricted to the place, as one participant stated: "It should be made clear that you are...not attempting to replace any other brand and that...it is not about organisational branding...just about the place” (P3). However, instances were reported where such acknowledgment was insufficient, (P6). It follows that the use of place visual identity is subject to stakeholder objectives, as one participant stated: "The university may use its own branding focusing on attracting students...staff...but promote [the place] to live and work etc... that is where city branding would be used in associations with theirs" (P6).

In order not to detract from or impose on stakeholder brands, in some instances the issue was resolved by requiring stakeholders to use the place name and nothing else (P5, P11). As one participant stated: "We wanted to put [the place] name...on the map for its products... eliminating the potential for any tensions... [as we are] asking them to put the name of [the] city at the forefront of what [they] do..they cannot object to that" (P5).

The "reality is that getting everybody working together is a very long term process" (P11) and while stakeholders will agree with the value of working together for consistent messaging if it conflicts with their objectives, alignment with the place brand architecture guidelines is discarded (P11).

Brand architecture is about collectively saying "look at what we produce...we are precious about everything to do with us as a working family" (P8), and thus becoming conspicuous amongst other places. The brand architecture guidelines should reflect unity and coherence. For instance, one participant explained that their branded house strategy uses three colours (yellow, blue, green) in the brand logo each reflecting a certain aspect of place; 
yellow highlights visitor attractions, blue highlights work and investment potential, and green focuses on living and higher education (P11).

\subsection{Stage 2: Exploring the web of brands associated with a place (objectives 2)}

\subsubsection{Web presences of cities}

Table 2 (Appendix A) provides a summary of the investigation into the digital presence of major regional cities within the UK. Each of these cities has an e-government (City Council) website, xxx.gov.uk, in addition to the websites listed in Table 2 (Appendix A). It is evident that the DMO website is not the only representation of the city in digital space. In addition, to the e-government websites, there are websites run by commercial concerns, including media and web technology companies, and interested residents. In order to explore in a basic manner whether there was any alignment between the representations of a given place between the City Council and the DMO websites that might be indicative of an aligned image and/or identity, we recorded our impressionistic judgement of the colour palette used on the websites for the major UK cities. This data is not presented in full here because it is surprisingly repetitive. Of the UK city websites, 17 had colour palettes that consisted primarily of different combinations and balances of white, black, grey and blue. This level of consistency suggests a level of web site design standardisation that may be more reflective of accessibility and readability than branding, and therefore it was difficult to draw conclusions as to the alignment between brand colour palettes for many of the places studied. There was, however, some evidence of alignment, and some of surprising misalignment. For instance, Edinburgh had blues, greys, and dark red on the City Council site, and black, purple, pink and pictures on the DMO site.

The final feature recorded in this phase was the extent of the use of the logos of other organisations associated with a place on the websites, either as an image, or as a clickable hyperlink to partners' sites. No such links were in evidence in the City Council sites in the UK. All links encountered on the DMO sites are recorded in Table 2 (Appendix A); these are few in number. Consistent with findings from Stage 1 of this study, the impression is of stand-alone web presences for place brands, with, in many cases, limited partnering or collaboration of any kind, let alone in relation to the development of the place brand. This suggests that many cities have not, for some reason chosen to or been able to capitalise on the potential benefits of a place brand architecture strategy (Hankinson, 2009). However, a notable exception that again aligns with findings from Stage 1, is the inclusion of links to the 
brands of smaller places within the geographical space associated with the brand for Birmingham, Liverpool and Canterbury, or to the county brands, especially when the city was the county city, as is evident for Oxford, Norwich, Canterbury, and Sheffield. Such links might be regarded as evidence of some development of sub-brand or house-of-brands strategies consistent with Uggla (2006) and Datzira-Masip and Poluzzi (2014).

\subsubsection{Liverpool's web of brands}

Phase 2 uses the case of a major UK City, Liverpool, to delve deeper into the range of brands, and their underlying organisations, that have the potential to impact on the brand identity or image associated with a place.

Historically, the urbanisation and expansion of Liverpool resulted through the city's status as a major port in the $18^{\text {th }} / 19^{\text {th }}$ century. However, since the decline of manufacturing and trade in the 1950's, a general economic and civic revival has been underway. As a result, in recent years Liverpool has won the right to be named European Capital of Culture 2008, beating other British cities such as Newcastle and Birmingham to the coveted title. The riverfront of the city was also designated as a World Heritage Site in 2004. The city authorities are eager to capitalise on the equity of such recognition and emphasise the city's cultural and other attractions. Tourism has become a significant factor in Liverpool's economy, capitalising on the popularity of The Beatles and other groups of the Merseybeat era. As such, the city has been experiencing continuous regeneration alongside a growing economy.

These activities have recently culminated in the development of the Liverpool city brand; 'It's Liverpool' with a web presence at www.itsliverpool.com. 'It's Liverpool' is the attack brand for Liverpool, and is managed by Marketing Liverpool, a Liverpool Vision initiative. Liverpool Vision is the city's official economic development agency, the economic arm of the city council; they also have a website, www.liverpoolvision.com. Finally, visitliverpool.com is the official tourism website for Liverpool City Region and promotes the city's attractions, events, sports and heritage. Each of these agencies contributes to the web of brands associated with the place, Liverpool. Moreover, Marketing Liverpool identifies 43 partners, ranging from independent businesses to multibillion pound organisations including private and public sector organisations, all of whom could be deemed to be committed to contributing to the place brand presences of Liverpool. Thus, the DMO is showing awareness of the need for a brand architecture (Anholt, 2004; Hankinson, 2005). However, only 12 of 
these use the logo 'It's Liverpool' on their web site and thus visually endorse the official city brand for Liverpool. This low level of commitment is consistent with Iversen and Hem (2008), who suggest that there are issues of engagement in respect of place brand architecture. The remaining 31 organisations, it could be argued, fall under the house-ofbrands approach with name Liverpool given little or no prominence, despite an acknowledged relationship on the DMO website. Finally, examination of the website, visitliverpool.com reveals an endorsed strategy employed to promote the sub-brands, Southport, Wirral, St. Helens, Knowsley and Halton, which is evidenced in earlier phases of this study and other research (Datizira-Masip \& Poluzzi, 2014; Uggla, 2006). The complexities of the Place Brand Web associated with Liverpool are further elaborated, and distilled into Figures 1(c) and 1(d) in the next section.

\section{Proposing, exemplifying and discussing the Place Brand Web (objective 3)}

While place branding theory has always recognised the need for community and stakeholder engagement (Briggs, 2009; Hankinson, 2007; Iversen \& Hem, 2008; Moilanen \& Rainisto, 2009), it has failed to develop models that adequately accommodate the complexity associated with multiple place brand owners. This situation becomes all the more complex when the brands associated with a given place are also taken into consideration, including corporate brands associated with the place, and the brands of 'sub-places'. Whilst previous case study research offers some interesting models of umbrella branding at the country level (Gnoth, 2002; Iversen \& Hem, 2008; Kavaratis, 2004; Trueman, Klemm \& Giroud, 2004), with some theoretical discussion of place brand architectures and brand webs (Anholt, 2004; Hankinson, 2005; Hanna \& Rowley, 2013), considerable benefits may be derived from a better understanding of the approaches adopted and the challenges experienced by place brand managers. However, it is possible that the current 'stakeholder' driven stance on seeking collaboration and buy-in to place brands is flawed, and that a theoretical model that views the owners of other brands associated with a place as partners between whom cobranding relationships can be developed, might be more fruitful. This would involve a change in stance from that adopted by, for instance, Datzira-Masip and Poluzzi (2014) and Kerr and Balakrishnan (2012) where the focus is on competition between place brands, to a perspective that views the brand associated with a place as 'contributing brands'. Consistent with this, Aitken and Campelo (2011) argue for a bottom-up approach to place branding, based on the paradigm of co-creation. 
Accordingly, following in the tradition of theories emerging in corporate co-branding, we propose the Place Brand Web Model (PBWM), as shown in Figure 1. Such conceptual frameworks have been proposed in the context of the creation and ongoing analysis of corporate brands and brand relationships (Leitch \& Richardson, 2003), and it seems that a parallel model might be useful for understanding and managing the relationships between the brands associated with a place. The Place Brand Web Model is depicted from two perspectives in Figures 1 (a) and 1(b); whilst Figures 1(c) and 1(d) use data from the exemplar city Liverpool to demonstrate the application of the Place Brand Web. Figure 1a shows the DMO-centric perspective which tends to pervade place branding literature; this perspective may be the most useful to practitioners. Figure $1 \mathrm{~b}$ shows THE Place Brand perspective, which positions THE Place Brand at the core of a co-creation process. THE Place Brand is a perceptual entity that has no evident representation as an independent brand. Apart from this unique characteristic, it shares other characteristics of a corporate brand, in that it is aligned with the place identity and determines the value sets which form the basis for the interaction with the other brands associated with the place.

Central to the PBWM is the concept of brand relationships, or more specifically, cobranding relationships. Co-branding involves the public linkage of partner brands in order to enhance the value of both brands (Motion, Leitch \& Brodie 2003). In the context of corporate brands, it typically involves a contractual relationship between the brand owners. In place branding, this is more likely to involve a negotiated, but dynamic agreement, based on perceptions of mutual benefit. In addition, to be successful it is widely acknowledged that co-branding should involve some alignment of brand core values, identities, communications and articulation, as the basis for transfer of positive image between the partners in the cobranding relationship (Motion, Leitch \& Brodie, 2003). For place branding such alignment would normally centre around the place identity, with all partners benefiting from a stronger and more coherent identity and its articulation (Cai, 2002; Hankinson, 2007; Pryor \& Grossbart, 2007; Hanna \& Rowley, 2013). It is unrealistic to expect that all partners will commit to the same level of partnership; their commitment will depend on their resources and the actual or potential value of the co-branding relationship to their organisation (Kahuni \& Rowley, 2013).

Figure 1a (the DMO centric perspective) provides typical exemplars of categories of brands associated with the place, listed in no particular order to the right of the DMO's scale of extent of collaboration. This scale embraces two types of branding partnerships between 
the DMO brand, sub-brands and co-brands. Sub-brands are brands that might traditionally be viewed as being within the brand portfolio of the DMO place brand. They are brands that have ceded control of the management of their brand identity, articulation and communication to the DMO, typically for legislative, financial, administrative or perceptual reasons. Sub-brands are typically brands for places and other agencies and bodies within the geographical region of the DMO place brand. They may in themselves also have unique, or place generic co-brands, in some of the categories shown in Figures 1a and 1b.

Co-brands are brands that are in no sense controlled by the DMO place brand, but recognise the benefit of associating themselves with the place. They have their own brand identity and fully developed brand articulation and communications. Their brand visibility and strategic success is not fully dependent on their relationship with the place brand. Cobranding can take a variety of different forms associated with different levels of commitment including placing logos on each other's documents and websites, promoting each other and developing a shared identity and articulation. Typically, co-branding partnerships do not extend to the co-branding partner adopting the place brand guidelines. The DMO's challenge is to develop fruitful co-branding partnerships with as many of the organisations in their geographical area who can add value to the overall place brand.

Figure $1 \mathrm{~b}$ responds specifically to the evidence that the entity being branded, a place, is dynamic and results from the interaction between the evolving identities and representations of its contributing brands. This is in accord with Merrilees, Miller and Herington's (2012) assertion that places have a multi-facetted identity, but goes further and suggests that this identity is unlikely to be fully represented by one brand, and can certainly be captured and represented differently in the identities associated with the different brands associated with a place. Therefore, in Figure 1b, the DMO-managed brand is only one brand that is consciously contributing to the perceptual entity, THE Place Brand. THE Pla Brô the place, and is co-created by the various contributing brand partnerships) or jusly (as a result of brand owners foctussingelely on their own brand). Thy uns and unconscious contributions are represented by the solid and broken arr ely (Figure 1b). 


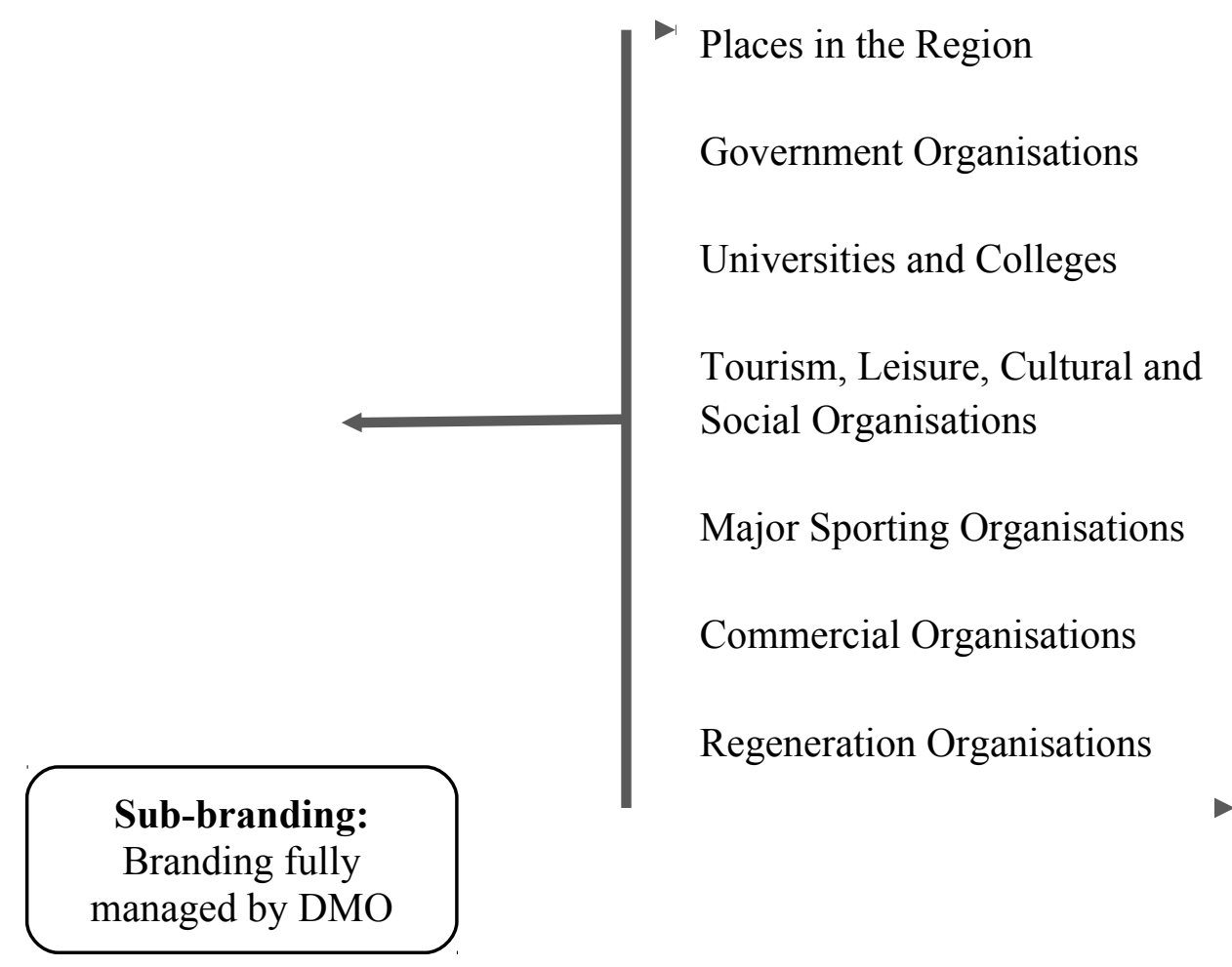

Figure 1a: Place Brand Web Model - the DMO partnership based perspective of place branding

associated with a place. This generic model will need to be adapted to suit specific places. In particular, since our research embraces towns, cities and regions, the Place Brand Web Model is intended to embrace all of these types of places. That is to say, unlike previous studies of umbrella branding (Iversen \& Hem, 2008; Therkelsen \& Halkier, 2008), the model does not consider country level place branding, nor does it focus solely on city branding. Essentially, the specific types of co-brands will vary from place to place, as will their significance.

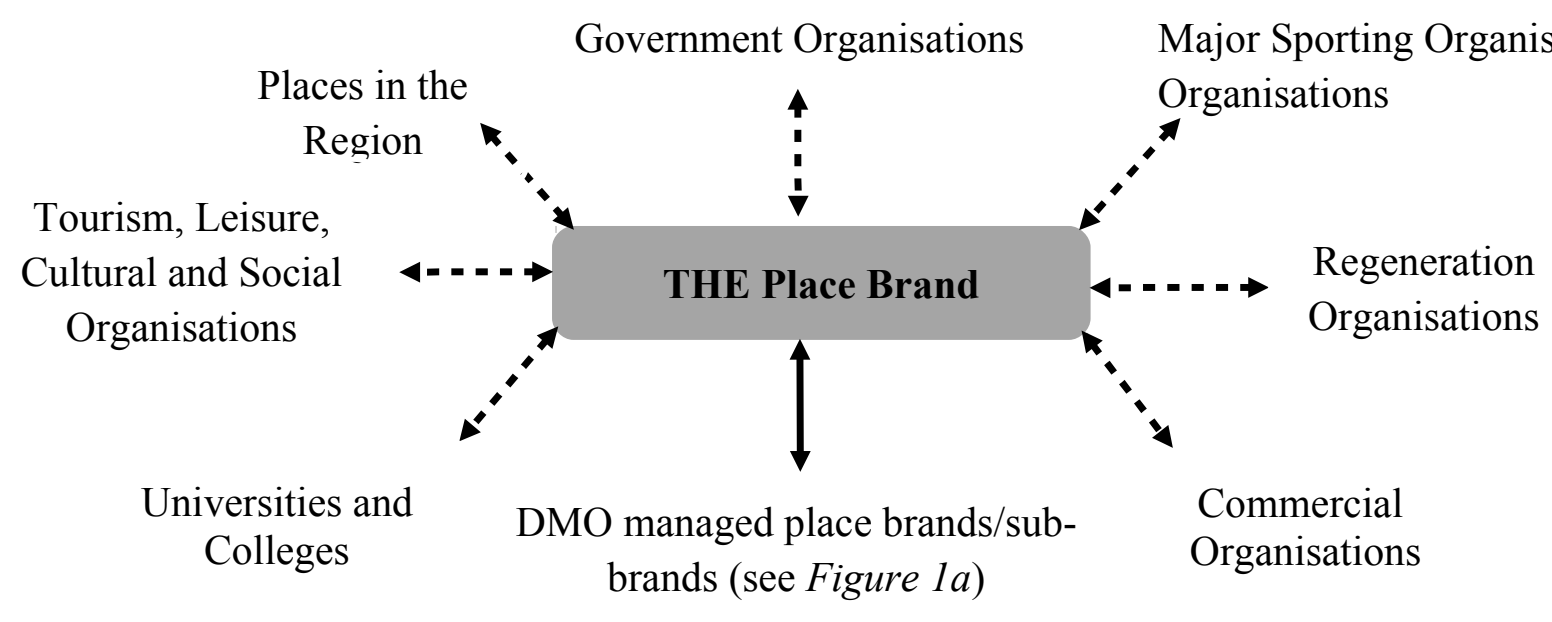


Figure 1b: Place Brand Web Model - The Co-creation of a perceptual entity, THE Place Brand

Figures $1 \mathrm{c}$ and $1 \mathrm{~d}$ are exemplars of the application of Figures $1 \mathrm{a}$ and $1 \mathrm{~b}$ to the city of Liverpool. Figure 1c provides examples of organisations that are in partnership with 'It's Liverpool', the DMO associated with the city. These organisations have their logo on the partners section of the 'It's Liverpool' website; they also include the 'It's Liverpool' logo on their website, to visually signify their collaboration with the place brand.

Two of the organisational categories shown in Figure 1a do not feature in Figure 1c; this is because, in the digital representation, as least, there is no evidence of the existence of a cobranding relationship in the case of the city of Liverpool. The first of these categories is 'Major Sporting Organisations' and the second is 'Places in the Region'. In respect of 'Places in the Region', there is no sub-branding of this type associated with 'It's Liverpool', although such sub-branding for 'Places in the region' does exist in connection with visitliverpool.com, the official tourism website for Liverpool City Region. Similarly, there are no major sporting organisations in partnership with 'It's Liverpool', yet, it is indisputable that, for example, Liverpool Football Club contributes to the promotion and identity of the place, Liverpool. Indeed, further examination of the organisations in Figure 1c, reveals other gaps at the level of specific organisations in the formal co-branding web of 'It's Liverpool'; for example, the University of Liverpool, and The Beatles Story are not in evidence in Figure 1c. This idiosyncratic position is evidence of the need for our two level model of the Place Brand Web. Figure 1d, illustrates how Figure 1b might be applied in practice, in this case to the perceptual entity of THE Place Brand, Liverpool. The categories in Figure 1d are the same as in Figure 1b. More categories and organisations are included than in Figure 1c. All of these branding entities contribute to the co-creation of the perceptual entity of THE Place Brand, Liverpool. Comparing Figures 1c and 1d demonstrates the limitations of viewing place brand webs from the perspective of the DMO and its branding partnerships. In addition, taking an overview of Figures $1 \mathrm{c}$ and $1 \mathrm{~d}$ demonstrates that many of the brands that contribute to the perceptual entity of the place brand have some stake in the tourism experience and in branding the destination (place). 
Liverpool, as a city, has significant organisations, many with strong brands of their own, in each of the categories in the Place Brand Web Model. This will not always be the case for smaller towns and cities, or for some regions, but the model can still be used as a conceptual framework.

This exemplar also illustrates that the brands associated with a place and contributing to the perceptual entity of THE Place Brand (Figure 1d) might have a variety of relationships with the place name, including:

1. Brands using the place name as part of their name e.g. Liverpool Football Club, University of Liverpool, Liverpool 1, Liverpool Chamber of Commerce, ACC Liverpool (arena and conventions centre), Royal Liverpool Philharmonic, Liverpool Community College, Shiverpool (ghost and history tour).

2. Brands using the place name in a brand strapline, or otherwise within their marketing, e.g. 'City, the magazine for Liverpool', 'DLIB, downtown Liverpool in Business', 'Liverpool's creative hub at the Bluecoat business club'.

3. Brands that are located in, and associated with a place, but do not use the place name explicitly in their branding or marketing (although it may appear in other descriptions, such as their address, or company details.) e.g. Milkytea (digital animation and illustration company), Aintree Racecourse, The Bluecoat Galleries, Leaf (independent tea shop), Epstein Theatre.

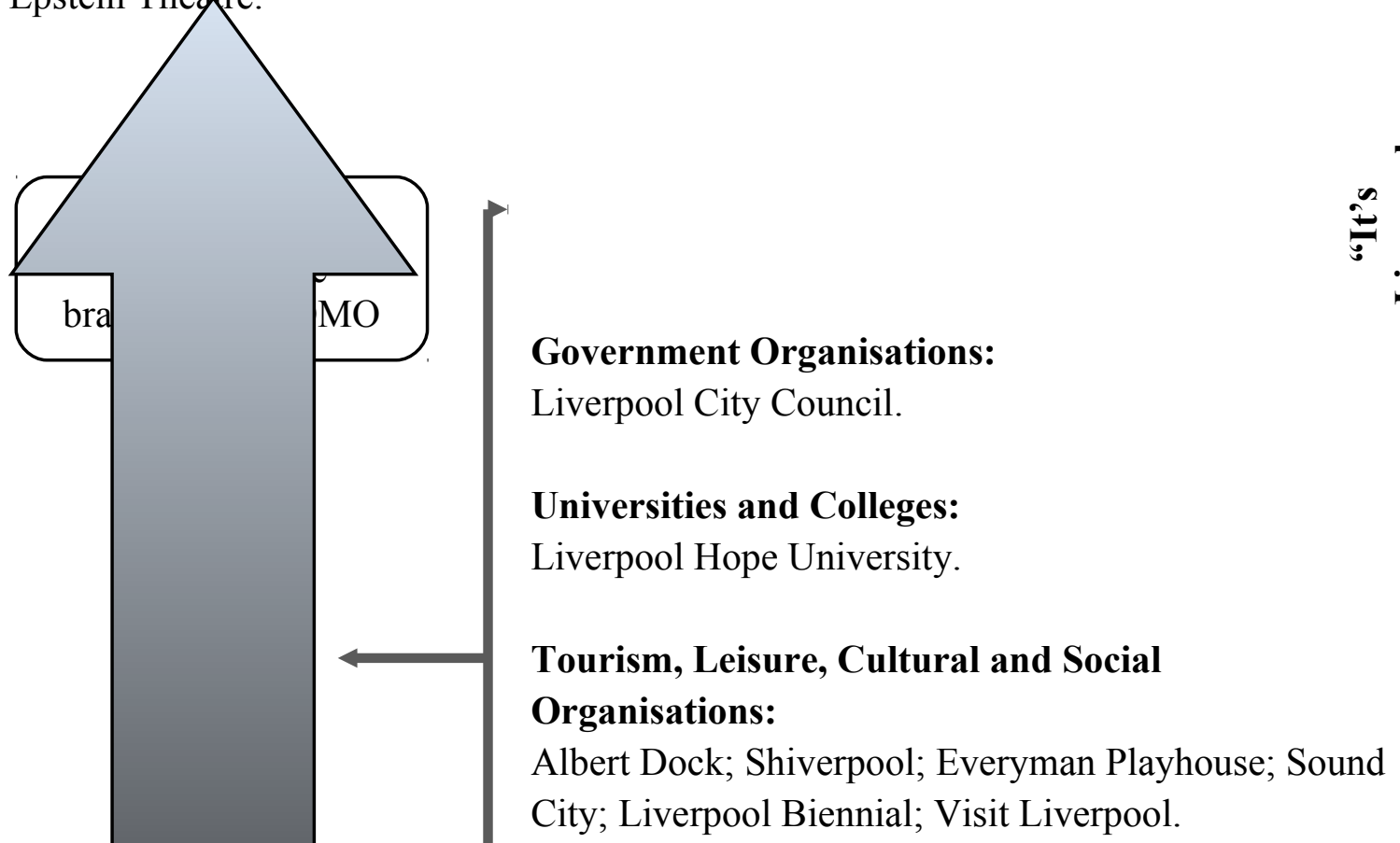

Commercial Organisations:

ACC Liverpool; Baltic Creative; FACT.

Regeneration Organisations:

Liverpool Vision. 


\section{Sub-branding:}

Branding fully managed by DMO

Figure 1c: Place Brand Web Model - Marketing Liverpool's partnership based perspective of place branding 
Government Organisations:

Liverpool City Council,

University Hospital, Liverpool,

Alder Hey Children's Hospital,

Mersey Rail,

Places in the Region: Mersey Travel,

Halton,

Liverpool Chamber of Commerce.

Major Sporting Organisations:

Wirral

Liverpool Football Club,

Everton football Club,

Aintree Racecourse.

Universities and Colleges:

University of Liverpool,

Liverpool John Moores University,

Liverpool Community College.

Tourism, Leisure, Cultural and Social Organisations:

Royal Liverpool Philharmonic,

National Museum Liverpool,

The Beatles Story,

Liverpool Cathedral,

Epstein Theatre,

Knowsley.

Liverpool 1,

The Blue Coat Galleries.

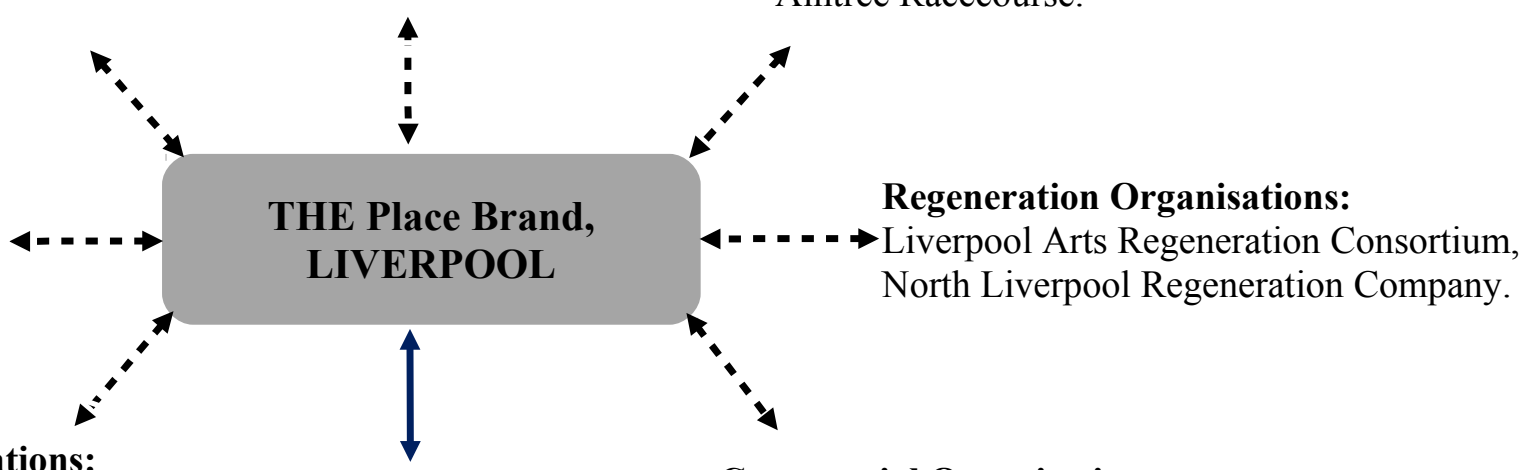

Figure 1d: Place Brand Web Model - The Co-creation of a perceptual entity,

THE Place Brand, Liverpool 


\section{Conclusions and Implications}

\subsection{Summary}

\subsubsection{Managing place brand architectures}

Participants in stage 1 of this study generally acknowledged the relevance and importance of brand architecture in the overall management process of the place brand. In particular, participant's consideration of the application of a specific strategy was dependent on consumer's perceptions of the place brand and its relationships to other places and stakeholder brands. Further, brand architecture was seen as a means of engaging stakeholders by indicating the benefits of communicating a unified and coherent place brand, although there was also recognition that stakeholders would priorities their own brands, over the place brand. On the other hand, the majority of the participants did not have an identifiable brand architecture, due mainly to the challenges they faced in engaging stakeholders to participate in the place brand architecture and to represent their engagement through the use of the place brand visual identity in their marketing communications. In addition, the study provides some evidence that the dynamic nature of the place brand may present practical challenges in aligning the place brands and other brands associated with the place. For instance, where participants did have an identified brand architecture strategy, this was typically used to make links between a region or a city and smaller towns within the region or city, and was achieved through what they perceived to be sub-brands for each of the associated places. This usually adopted the 'Branded-house' strategy, with brand livery and design being used across the portfolio of sub-places. There was little evidence of consideration of other options that might contribute to the creation of a more holistic approach to 'branding their place', as opposed to 'place branding'. Yet, especially in the Internet era, stakeholders and potential stakeholders far and near can discern all too clearly that a given place may have more than one place brand instantiation.

\subsubsection{The Place Brand Web}

The initial exploration of the brands associated with a place, in this case UK cities, showed that there are a number of organisations that brand any given place, and the level of alignment between these brands as indicated by key elements of the brand livery, such as colour is variable. In addition, there was very little evidence of links between the web-sites, in the form of the use of logos of other organisation associated with the place, suggesting limited partnering or collaboration around the place brand and its identity. 
Building on this overview, the second phase of Stage 2 undertook a more detailed analysis of the brands associated with the city of Liverpool. This centred on, but was not restricted to 'It's Liverpool', the attack brand for Liverpool, which is managed by Marketing Liverpool. Marketing Liverpool identify 43 partners, all of whom could be deemed to be committed to contributing to the place brand presence and identity of Liverpool, however, only 12 of these use the logo 'It's Liverpool' on their website. Using Liverpool as an illustration, we propose the Place Brand Web Model, which encompasses both co-branding and sub-branding relationships, and offers a taxonomy of the types of organisations that can potentially be involved in the web of brands associated with a place. Further, we argue that it is important to differentiate between the DMO's perspective on the web of brands, and the actual web of brands that contribute to the perceptual entity, THE Place Brand. This proposed model of the Place Brand Web constitutes a considerable advance on previous models of the brands associated with a place, in that instead of accepting the straightjacket of the theoretical notion of brand architecture, it adopts the more permissive and flexible concept of the brand web to encompass a wide range of brand relationships, between organisations and places that have varying levels of autonomy.

\subsection{Research, theoretical implications and limitations}

Whilst this study explores approaches to places' brand architecture management across a number of towns, cities, and regions, and proposes a conceptual model of the place brand web, there is considerable scope for further development of understanding of the nature of place brand architecture, how it is managed, and how it might be managed to good effect.

Evidence both from practitioners, and from web communications relating to places, suggests that the explicit management of place brand webs is complex and difficult to effect. Hence, there is a need for further research into the nature of place brand architectures and webs, and the management of the constituent relationships between these brands. Much prior research has been dedicated to eliciting and managing stakeholder engagement with the DMO's vision of the place and its brand (Hankinson 2004, 2009; Zineldin, 2004), but insufficient research has focussed on the specific mutual benefits that might accrue from such engagement. In addition, in the digital and social media arena, there is increasing awareness that customers, citizens and communities are participating in the co-creation of brands and that brand owners need to relinquish control (Andehn, Kazeminia, Lucarelli \& Sevin, 2014; Aitkens \& Campelo, 2011). According to Kavaratzis (2012), there is an urgent need to re- 
think place branding towards a more participatory model, which fully acknowledge stakeholders' role in legitimising place brands and in influencing their meaning. Research is required to establish the theoretical frameworks for such a participatory model, and to explore how it might work in practice, across the web of brand relationships associated with a place. Taking this further, both theoretically and practically, it would be valuable to develop an understanding of the value created through place brand relationships, including both its nature and extent. Moreover, given that in the digital arena audiences are exposed to a wide range of different instantiations of the brand, research should investigate the effect of this on perceptions of the place brand image's focus and distinctiveness. Since every place is different, case study research can make a valuable contribution towards developing a deeper understanding of the links that exist between the brands that are owned by different stakeholders, yet are associated with a place. Such research might focus on the drivers, and success factors associated with building relationships, and strengthening the coherence of an overarching place brand web.

Finally, our proposed model could be further elaborated and exemplified to: accommodate representation of the links between the brands in the Place Brand Web; represent the different types of links, such as contractual, involvement, and perceptual; be used as a basis for exploring the impact of links on the overall identity and perceptions of the THE Place Brand; and, accommodate different types of place brand entities, such as regions, and countries.

\subsection{Practitioner implications}

The study both offers a number of insights into practices associated with place brand architecture, which can be used to inform and benchmark practice, and also proposes the Place Brand Web Model, which can be used by tourism and other organisations to audit their existing and potential place brand web. In particular, practitioners could use the Place Brand Web Model as a basis for creating their own model of the web of brands associated with their place. They could use such a model in auditing the existing status of their place brand web, and also in developing a coherent summary of their future aspirations. In addition, they may choose to use the model in their dialogues with other place stakeholders, with the aim of establishing and sustaining a dialogue around THE Place Brand identity, and establishing the contribution and commitment of various stakeholders to its articulation and evolution. Thinking at the level of the perceptual links between brands, and the benefits to be accrued by strengthening those links, either instead of, or considering their relationships and 
interactions with the stakeholders owning those brands will lift reflection to a level that focuses on the strategic objective of building the perceptual entity of THE Place Brand. Moreover, the Place Brand Web Model invites brand and tourism practitioners to think about the place's portfolio of brands not just in terms of administrative boundaries, but also to acknowledge cultural, sporting, leisure, historical and other perceptual entities that contribute to the co-creation of the tourism and wider place experience.

Overall, this article invites place brand practitioners to develop their understanding of the place brand web associated with their place, and to investigate and develop an understanding of its nature, role and importance. For example, it may be useful for practitioners to undertake a mapping exercise to evaluate the relative impact of the places' different brands (including the one that they are responsible for) on the overall coherence of perceptions of THE Place Brand. This, in turn may strengthen practitioners capacity to develop and evolve a place brand identity that has resonance across the brand portfolio, and to undertake practical actions, such as agreed visual identity guidelines, and the wider use of logos across the brand communications of the brands within the place brand web.

\section{REFERENCES}

Aaker, D. \& Joachimsthaler, E. (2000). The brand relationship spectrum: key to the brand architecture challenge. California Management Review, 42, 8-23.

Aitken, R., \& Campelo, A. (2011). The four Rs of place branding. Journal of Marketing Management, 27, 913-933.

Allen, G. (2007). Place branding: new tools for economic development. Design Management Review, 18, 60-68.

Anholt, S. (2004). Foreword. Place Branding and Public Diplomacy, 1, 4-11.

Andehn, M., Kazeminia, A., Lucarelli, A., \& Sevin, E. (2014). Uder-generated place brand equity on Twitter: The dynamics of brand associations in social media. Place Branding and Public Diplomacy, 10, 132-144.

Baker, B. (2007), Destination branding for small cities: Essentials for successful place branding, Creative Leap Books.

Bennett, R., \& Savani, S. (2003). The re-branding of city places: an international comparative investigation. International Public Management Review, 4, 70-87.

Braun, E. \& Zenker, S. (2010). Towards an integrated approach for place brand management. $50^{\text {th }}$ European Regional Science Association Congress, Jonkoping, 
Sweden,

available

at:

www.sre.wu.ac.at/ersa/ersconfs/ersa10/ERSA2010finalpaper181.pdf

(accessed: 06/06/2014).

Briggs, M. (2009). Innovation and the city: a macro marketing approach to industry development. Marketing Intelligence and Planning, 27, 233-245.

Bryman, A. \& Bell, E. (2011). Business research methods. $3^{\text {rd }}$ Ed. Oxford, Oxford University Press.

Burmann, C., \& Zeplin, S. (2005). Building Brand commitment: a behavioural approach to internal brand management. Journal of Brand Management, 12, 279-300.

Cai, L. (2002). Cooperative branding for rural destinations. Annals of Tourism Research, 29, 726-742.

Creswell, J. (1998). Qualitative inquiry and research design: Choosing among five traditions. London: Sage.

Creswell, J. (2007). Qualitative inquiry and research design: choosing among five approaches, $2^{\text {nd }}$ Ed. London, Sage.

Chen, A. \& Chen, S. (2000). Brand dilution effect of extension failure - a Taiwan study. Journal of Product and Brand Management, 9, 243-254.

Clarkson, M. (1995). A stakeholder framework for anlayzing and evaluating corporate social performance. Academy of Management Review, 20, 92-117.

Datzira-Masip, J., \& Poluzzi, A. (2014). Brand architecture management: The case of four tourist destinations in Catalonia. Journal of Destination Marketing and Management, 3, 48-58.

Donaldson, T., \& Preston, L. (1995). The stakeholder theory of the corporation: Concepts, evidence, and implications. Academy of Management Review, 20, 65-91.

Dooley, G., \& Bowie, D. (2005). Students' Corner - Place brand architecture: strategic management of brand portfolio. Place Branding, 1, 402-419.

Douglas, S., \& Craig, S. (2002). Executive insights - integrating branding across markets: building international brand architecture. Journal of International Marketing, 9, 97114.

Eshuis, J., Braun, E., \& Klijn, E-H. (2013). Place marketing as governances strategy: an assessment of obstacles in place marketing and their effects on attracting target groups. Public Administration Review, 70, 507-516. 
Gnoth, J. (2004). Opinion pieces: where is place branding heading. Place Branding, 1, 1235.

Gnoth, J. (2002). Leveraging export brands through a tourism destination brand. Journal of Brand Management, 9, 262-280.

Gnoth, J. (2011). Destination brand architecture, in: Gross, M J (Ed). CAUTHE 2011: National Conference: Tourism: Creating a Brilliant Blend. Adelaide, S. A: University of South Australia. School of Management, 2011: 227-238. Available at: http://search.informit.com.au/documentSummary; $\mathrm{dn}=902526209981793 ;$ res=IELBUS (accessed: 06/06/2014).

Gold, E. (2006). Intellectual architecture as a place brand. Place Branding, 2, 220-228.

Gray, D. (2009). Doing research in the real world. $2^{\text {nd }}$. Ed. London, Sage.

Guest, G., Bunce, A., \& Johnson, L., (2006). How Many Interviews are Enough? An Experiment with Data Saturation and Variability. Field Methods, 15, 59-82.

Guy, J. (2005). Urban designscapes and the production of aesthetic consent. Urban Studies, $42,869-887$.

Hankinson, G. (2001). Location branding: a study of the branding practices of 12 English cities. Journal of Brand Management, 9, 127-142.

Hankinson, G. (2004). Relational network brands: towards a conceptual model of place brands. Journal of Vacation Marketing, 10, 109-121.

Hankinson, G. (2005). Destination Brand Images: a business tourism perspective. Journal of Services Marketing, 19, 24-32.

Hankinson, G. (2007). The management of destination brands: five guiding principles based on recent development in corporate branding theory. Journal of Brand Management, $14,240-254$.

Hankinson, G. (2009). Managing destination brands: establishing a theoretical framework. Journal of Marketing Management, 25, 97-115.

Hanna, S., \& Rowley, J. (2011). Towards a strategic place brand-management model. Journal of Marketing Management, 27, 458-476.

Hanna, S., \& Rowley, J. (2013). A practitioner-led strategic place brand management model. Journal of Marketing Management, 29, 1782-1815.

Hudson, S., \& Ritchie, B. (2009). Branding a memorable destination experience: the case of 'Brand Canada'. International Journal of Tourism Research, 11, 217-228. 
Iversen, N., \& Hem, L. (2008). Provenance associations as core values of place umbrella brands: a framework of characteristics. European Journal of Marketing, 42, 603-62.

Jones, T. (1995). Instrumental Stakeholder Theory: A Synthesis of Ethics and Economics. The Academy of Management Review, 20, 404-437.

Kahuni, A., \& Rowley, J. (2013). Corporate brand relationships: the case of TOYOTA F1 Racing Team. Sport, Business and Management: An International Journal, 3, 8-18.

Kavaratzis, M. (2004). From city marketing to city branding: toward a theoretical framework for developing city brands. Place Branding, 1, 58-73.

Kavaratzis, M. (2012). From 'necessary evil' to necessity: stakeholders involvement in place branding. Journal of Place Management and Development, 5, 7-19.

Kerr, G. (2006). From Destination Brand to Location Brand. Journal of Brand Management, 13, 276-283.

Kerr, G. (2012). Challenges in managing place brands: The case of Sydney. Place Branding and Public Diplomacy, 8, 6-16.

Kerr, G., \& Balakrishnan, M. (2012). Challenges in managing place brands: the case of Sydney. Place Branding and Public Diplomacy, 8, 6-16

Kokosalakis, C., Bagnall, G., Selby, M., \& Burns, S. (2006). Place image and urban regeneration in Liverpool. International Journal of Consumer Studies, 30, 389-397.

Kotler, P., \& Gertner, G. (2002). Country as a Brand, Product and Beyond: a place marketing and brand management perspective. Journal of Brand Management, 9, 249-262.

Knox, S., \& Burkard, A. (2009). Qualitative Research Interviews. Psychotherapy Research, 19, 566-575.

Kvale, S., \& Brinkmann, S. (2009). Interviews: learning the craft of qualitative research interviewing, Thousand Oaks, Sage.

Leitch, S., \& Richardson, N. (2000). Co-branding organizations: the communication of multiple corporate identities in the age of electronic commerce. Paper presented at the Australia and New Zealand Communication Association Annual Conference, Ballina, July.

Leitch, S., \& Richardson, N. (2003). Corporate branding in the new economy. European Journal of Marketing, 37, 1065-1079.

Lodge, C. (2004). Opinion pieces: Where is place branding heading? Place Branding and Public Diplomacy, 1, 12-35. 
Martinexz, E., \& Pina, J. (2003). The negative impact of brand extensions on partner brands. Journal of Product and Brand Management, 12, 432-448.

McCarthy, J. (2007). Partnership, collaborative planning and urban regeneration, Aldershot, Ashgate.

Merrilees, B., Miller, D., \& Herington, C. (2012). Multiple stakeholders and multiple city meanings. European Journal of Marketing, 46, 1032-1047.

Mihailovich, P. (2006). Kinship branding: a concept of holism and evolution for the nation brand. Place Branding, 2, 229-247.

Miller, K. (2002). Competitive strategies of religious organisations. Strategic Management Journal, 23, 435-456.

Moilanen, T., \& Rainisto, S. (2009). How to brand cities, nations and destinations: a planning book for place branding. Basingstoke, Palgrave Macmillan.

Morgan, N., Pritchard, A., \& Pride, R. (2004). Destination Branding: creating a unique destination proposition. Elsevier, Butterworth Heinemann.

Motion, J., Leitch, S., \& Brodie, R. (2003). Equity in corporate co-branding: the case of Adidas and the All Blacks. European Journal of Marketing, 37, 1080-1094.

Moustakas, C. (1994). Phenomenological research methods, Thousand Oaks, Sage.

Munar, A. (2011). Tourist-created content: rethinking destination branding. International Journal of Culture, Tourism and Hospitality Research, 5, 291-305.

Olins, W. (2002). Branding the nation - the historical context. Journal of Brand Management, 9, 241-248.

Olins, W. (2003). Hull: pioneering city, case study'. Retrieved from: www.wolffolins.com/files/Hull 0202New815000.pdf (accessed 20/11/2012).

Ooi, C. (2004). Poetics and politics of destinational branding: Denmark. Scandinavian Journal of Hospitality and Tourism, 4, 107-128.

Park, S-Y., \& Petrick, J. (2006). Destinations' Perspectives of Branding. Annals of Tourism Research, 1, 262-265.

Papadopoulos, N., \& Helsop, L. (2007). Country equity and country branding: problems and Prospects. Journal of Brand Management, 9, 294-314.

Peel, D., \& Lloyd, G. (2008). New communicative challenges: Dundee, place branding and the reconstruction of a city image, Town Planning Review, 79, 507-532. 
Polkinghorne, D. (1989). Phenomenological research methods. In Valle, R., and Halling, S., (Eds.), Existential Phenomenological Perspectives in Psychology (41-60). New York: Plenum.

Pryor, S., \& Grossbart, S. (2007). Creating Meaning on the street: towards a model of place branding. Place branding and Public Diplomacy, 3, 291-304.

Sanchez, R. (2004). Conceptual analysis of brand architecture and relationships within product categories. The Journal of Brand Management, 11, 233-247.

Riege, P., Perry, C., \& Go, F. (2001). Partnerships in international travel and tourism marketing: a systems-orientated approach between Australia, New Zealand, Germany and United Kingdom. Journal of Travel and Tourism Marketing, 11, 59-77.

Rubenstein, H. (1996). Brand first - management. Journal of Marketing Management, 12, 269-280.

Sautter, E., \& Leisen, B. (1999). Managing stakeholders: a tourism planning model. Annals of Tourism Research, 26, 312-323.

Simoes, C., \& Dibb, S. (2001). Rethinking the brand concept: a new brand orientation. Corporate Communications, 6, 217-224.

Stubbs, B., Warnaby, G., \& Medway, D. (2002). Marketing at the Public/Private Sector Interface; Town Centre Management Schemes in South of England. Cities, 5, 317326.

Therkelsen, A., \& Halkier, H. (2008). Contemplating place branding umbrellas: the case of coordinated national tourism and business promotion in Denmark. Scandinavian Journal of Hospitality and Tourism, 8, 159-175.

Trueman, M., Klemm, M., \& Giroud, A. (2004). Can a city communicate? Bradford as the corporate brand. Corporate Communications: An International Journal, 9, 317-330.

Treman, M., Cornelius, N., \& Wallace, J. (2012). Building brand value online: exploring relationships between company and city brands. European Journal of Marketing, 47, 1013-1031.

Uggla, H. (2006). The corporate brand association base: a conceptual model for the creation of inclusive brand architecture. European Journal of Marketing, 40, 785-802.

Vallaster, C., \& DeChernatony, L. (2006). Internal brand building and structuration: the role of leadership. European Journal of Marketing, 40, 761-784. 
Van Assche, K. \& Lo, M. (2011). Planning, preservation and place branding: a tale of sharing assets and narratives. Journal of Place Branding and Public Diplomacy, 7, 117-126.

Van Ham, P. (2001). The rise of brand state: the post modern politics of image and reputation. Foreign Affairs, 80, 2-6.

Warnaby, G. (2009). Towards a service-dominant place marketing logic. Marketing Theory, 9, 403-423.

Yin, R. (2009). Case Study Research: Design and Methods 4th, ed., London, Sage.

Zineldin, M. (2004). Co-opetition: the organisation of the future. Marketing Intelligence and Planning, 22, 780-789. 
Appendix A - TABLE 2: Place websites identified and visited for selected major cities in the UK

\begin{tabular}{|c|c|c|c|c|}
\hline CITY & $\begin{array}{l}\text { OFFICIAL DMO } \\
\text { WEBSITE }\end{array}$ & OPERATOR & OTHER WEBSITES & LINKS/OTHER LOGOS ON WEBSITE \\
\hline London & Visitlondon & $\begin{array}{l}\text { London.gov.uk, greater London } \\
\text { Authority }\end{array}$ & $\begin{array}{l}\text { London.com, run by local } \\
\text { residents, Londontown.com }\end{array}$ & \\
\hline Aberdeen & aberdeen.grampian.com & VisitScotland/Inc. & & VisitScotland logo \\
\hline Birmingham & Visitbirmingham.com & VisitBirmingham & & $\begin{array}{l}\text { Visitsolihull, and visit the Black Country } \\
\text { logos }\end{array}$ \\
\hline Bristol & Visitbristol.co.uk & Destination Bristol & & \\
\hline Canterbury & Canterbury.co.uk & VisitCanterbury & & $\begin{array}{l}\text { Canterbury City Council logo } \\
\text { Links through to sub-places: Herne Bay, } \\
\text { Whitstable. }\end{array}$ \\
\hline Cardiff & visitcardiff.com & & $\begin{array}{l}\text { Cardiff.co.uk, run by Geoware } \\
\text { Media }\end{array}$ & \\
\hline Edinburgh & Edinburgh.org & VisitScotland & & $\begin{array}{l}\text { Edinburgh World Heritage City, and } \\
\text { VisitScotland logos. }\end{array}$ \\
\hline Exeter & & & $\begin{array}{l}\text { Exeter.co.uk, run by Geoware } \\
\text { Media } \\
\text { Thisisexeter.co.uk, run by Exeter } \\
\text { Express \& Echo }\end{array}$ & \\
\hline Glasgow & Seeglasgow.com & Glasgow City Marketing Bureau & & ScotlandwithStyle logo \\
\hline Leeds & Visitleeds.co.uk & Leeds and Partners & & \\
\hline Liverpool & It's Liverpool & $\begin{array}{l}\text { Marketing Liverpool (Liverpool } \\
\text { Vision initiative) }\end{array}$ & $\begin{array}{l}\text { Visitliverpool.com, run by } \\
\text { Liverpool City Region Local } \\
\text { Entreprise Partnership. } \\
\end{array}$ & $\begin{array}{l}\text { Links through to sub-places: Halton, } \\
\text { Southport,etc. }\end{array}$ \\
\hline Manchester & Visitmanchester.com & VisitManchester & & Visit England logo \\
\hline Norwich & Visitnorwich.co.uk & VisitNorwich. & & $\begin{array}{l}\text { Links, but no logos, to Norfolk.gov.uk, and } \\
\text { other Norwich and Norfolk tourist } \\
\text { information sources. }\end{array}$ \\
\hline Oxford & $\begin{array}{l}\text { Visitoxfordandoxfordshire.c } \\
\text { om. }\end{array}$ & Visit Oxfordshire & $\begin{array}{l}\text { OxfordCityGuide.com, run by a } \\
\text { local resident } \\
\text { Oxfordcity.co.uk run by OXLINK } \\
\text { Web Design }\end{array}$ & The Beautiful South, and Visit Britain logos \\
\hline Sheffield & Welcometosheffield.co.uk & Marketing Sheffield & $\begin{array}{l}\text { Sheffield.co.uk, run by } \\
\text { WebTechnik }\end{array}$ & $\begin{array}{l}\text { Sheffield City Council, Welcome to } \\
\text { Yorkshire, Peak District }\end{array}$ \\
\hline Southampton & Visit-southampton.co.uk & Visit Southampton & & \\
\hline
\end{tabular}

